\title{
New cases of HIV/AIDS in adults during 2007-2012
}

\author{
Andreea Cristina Stoian ${ }^{1,2^{*}}$, Constantin Bănică², Loredana lonescu², Augustin Cupşa ${ }^{1,2}$, Lucian Giubelan ${ }^{1,2}$, \\ Florentina Dumitrescu ${ }^{1,2}$ \\ From The 9th Edition of the Scientific Days of the National Institute for Infectious Diseases Prof Dr Matei Bals \\ Bucharest, Romania. 23-25 October 2013
}

\section{Background}

We analyzed the epidemiological and clinical aspects in patients newly diagnosed with HIV.

\section{Methods}

We performed a retrospective, compared study, in the Regional Monitoring and Evaluation of HIV/AIDS from Craiova, between 01 January 2007 - 31 December 2012, in two groups of patients with HIV/AIDS, as follows: group A-59 patients diagnosed with HIV/AIDS in the period 01 January 2010 - 31 December 2012 and group B-113 patients diagnosed with HIV/AIDS in the period 01 January 2007 - 31 December 2009, the results analyzed were: clinical, epidemiological, immunological and virological evolution in the first 12 months of screening. For statistical analysis we used the Epi Info program, threshold (p) values are statistically significant at $\leq 0.05$.

\section{Results}

Demographic data for group A vs. group B: female $/$ male = $16(27.11 \%) / 43$ (72.88\%) vs. 61 (53.98\%) / 52 (46.02\%); $\mathrm{p}=0.0011, \mathrm{urban} / \mathrm{rural}=30(50.84 \%) / 29(49.15 \%)$ vs. $=65$ (57.52\%) / 48 (42.47\%), $\mathrm{p}=0.42$; probable route of transmission: sexual/horizontal, in early childhood / i.v. drugs = 49 (83.05\%) / 9 (15.24\%) / 1 (1.69\%) vs. $62(50.44 \%) / 51$ (45.13\%) $\mathrm{p}=0.002$; the average age (years): $31.2 \pm 10.98$ vs. $24.5 \pm 12.25 ; \mathrm{p}=0.0005$; the average $\mathrm{CD} 4$ count $=323.14$ \pm 161.57 vs. $209.22 \pm 104.61$ cells $/ \mathrm{cmm} ; \mathrm{p}=0.86$, the average HIV viral load $=5.4 \log$ copies $/ \mathrm{mL}$ vs. $4.9 \log$ copies $/ \mathrm{mL}$, clinical and immunological distribution: B3 $=11(18.64 \%)$ vs. $18(15.92 \%), \mathrm{C} 3=15(25.42 \%)$ vs. $43(38.05 \%)$, the symptomatic/asymptomatic onset $=45(76.27 \%) / 14$ $(23.72 \%)$ vs. $80(70.79 \%) / 33$ (29.20\%); $\mathrm{p}=0.47$, the most common opportunistic infection is pulmonary tuberculosis $=19(32.20 \%)$ vs. 31 (27.43\%); $\mathrm{p}=0.59$; administration of

\footnotetext{
* Correspondence: andreea_plr@yahoo.com

'University of Medicine and Pharmacy Craiova, Romania

Full list of author information is available at the end of the article
}

ART: 45 (76.27\%) vs. 80 (70.79\%); deaths in the first 12 months of detection $=2(3.38 \%)$ vs. $3(2.65 \%) ; \mathrm{p}=1.000$.

\section{Conclusion}

The new cases of HIV infection in 2007-2009 were lower than during 2010-2012, when the route of sexual transmission was predominant, male sex is more commonly affected, and the average age is elder. Mortality remained at a low rate, but similar in both periods followed (20072009 vs. 2010-2012). Tuberculosis was the most common opportunistic infection in HIV detection, independently of the period followed.

\section{Authors' details}

"University of Medicine and Pharmacy Craiova, Romania. " "Victor Babeş" Clinical Hospital of Infectious Diseases and Pneumology, Craiova, Romania.

Published: 16 December 2013

doi:10.1186/1471-2334-13-S1-P6

Cite this article as: Stoian et al: New cases of HIV/AIDS in adults during 2007-2012. BMC Infectious Diseases 2013 13(Suppl 1):P6.

Submit your next manuscript to BioMed Central and take full advantage of:

- Convenient online submission

- Thorough peer review

- No space constraints or color figure charges

- Immediate publication on acceptance

- Inclusion in PubMed, CAS, Scopus and Google Scholar

- Research which is freely available for redistribution

Submit your manuscript at www.biomedcentral.com/submit

\section{() Biomed Central}

\section{Biomed Central}

(c) 2013 Stoian et al; licensee BioMed Central Ltd. This is an Open Access article distributed under the terms of the Creative Commons Attribution License (http://creativecommons.org/licenses/by/2.0), which permits unrestricted use, distribution, and reproduction in any medium, provided the original work is properly cited. 